\title{
Online Survey Application System Design Via Telegram at the Bsa Project Surabaya Company
}

\section{Rancang Bangun Sistem Aplikasi Survei Online Via Telegram Pada Perusahaan Bsa Project Surabaya}

\author{
Wahyu Ardian Saputro ${ }^{1)}$, Mohammad Suryawinata ${ }^{2)}$ \\ $\left\{151080200097 @ u_{\text {umsida.ac.id }}^{1)}\right.$, suryawinata@umsida.ac.id $\left.{ }^{2)}\right\}$ \\ ${ }^{1,2}$ Program Studi Informatika, Fakultas Sains dan Teknologi \\ Universitas Muhammadiyah Sidoarjo, Indonesia \\ Jl. Raya Gelam No. 250, Candi, Sidoarjo, 61271
}

\begin{abstract}
To improve the quality of service at BSA Project companies, it is necessary to survey how the results of the performance of BSA Project employees in serving customers, so that the results of the survey can be a company benchmark in evaluating and correcting if an error occurs. Making an Online Survey Application System Via Telegram at the BSA Project Surabaya Company which can be one of the benchmarks for companies to monitor and evaluate the performance of employees for service to customers. Supporting subjects in making this application are all employees in the Surabaya BSA Project Company. The application of the online survey application can be implemented using a php server. This online survey web application can also be connected to the telegram application, and the results can be displayed in real time. Testing the basic functions of the system that is done directly can be concluded that this application program can run as expected, then the results of the user acceptance test that has been tested on 20 employees can be known that the percentage for agreed responses is between $80 \%$ to $100 \%$, then the choice to disagree is between $0 \%$ to $20 \%$, for that it can be concluded that the majority of user responses in using this application program are agreed and this application program can be well received by BSA Project Surabaya employees.
\end{abstract}

Keywords - Online survey, Telegram, BSA Project

\begin{abstract}
Abstrak.Untuk meningkatkan kualitas pelayanan pada perusahaan BSA Project perlu untuk mensurvei bagaimana hasil kinerja para karyawan BSA Project dalam melayani para customer,sehingga dari hasil survei tersebut dapat menjadi tolak ukur perusahaan dalam mengevaluasi serta membenahi apabila terjadi kesalahan. Pembuatan Sistem Aplikasi Survei Online Via Telegram Pada Perusahaan BSA Project Surabaya yang dapat menjadi salah satu tolak ukur bagi perusahan untuk monitoring dan mengevaluasi kinerja para karyawan terhadap pelayanan kepada pelanggan. Subjek pendukung dalam pembuatan aplikasi ini adalah seluruh karyawan dalam Perusahaan BSA Project surabaya, Penerapan aplikasi Survei online dapat di implementasikan dengan menggunakan server php. Aplikasi Web survei online ini juga dapat dikoneksikan dengan aplikasi telegram, serta hasil nya dapat ditampilkan secara realtime. Pengujian fungsi dasar sistem yang di lakukan secara langsung dapat di simpulkan bahwa program aplikasi ini dapat berjalan sesuai harapan, kemudian pada hasil uji coba user acceptance test yang telah di ujikan kepada 20 karyawan dapat di ketahui bahwa presentase untuk tanggapan setuju adalah antara $80 \%$ sampai $100 \%$, lalu pada pilihan untuk tidak setuju adalah antara 0\% sampai $20 \%$, untuk itu dapat disimpulkan bahwa mayoritas tanggapan user dalam penggunaan program aplikasi ini adalah setuju dan program aplikasi ini dapat di terima dengan baik oleh karyawan BSA Project Surabaya.
\end{abstract}

Kata kunci - Survei online, Telegram, BSA Project

\section{PENDAHULUAN}

Survei merupakan suatu untuk menentukan hubungan-hubungan antar variabel serta membuat generalisasi untuk suatu populasi yang dipelajari.[1]. Survei mampu mengerjakan hal tersebut karena prosedur pengumpulan data yang 
di pergunakan telah dibuat seragam dan telah distandarisasikan. Individu-individu yang dipilih dalam contoh (sample) dihadapkan pada sejumlah pertanyaan yang telah ditetapkan. Jawaban dari pertanyaan diklasifikasikan secara sistematis, sehingga dapat dibuat perbandingan-perbandingan kuantitatif.[2]. lalu dalam riset pendidikan, survei bukan semata-mata dilakukan untuk mengumpulkan data atau informasi, seperti tentang pendapat atau sikap, tetapi juga untuk membuat deskripsi komprehensif maupun untuk menjelaskan hubungan antar berbagai variabel yang diteliti [3].metode survei adalah Penelitian yang dilakukan dengan menggunakan angket sebagai alat penelitian yang dilakukan pada populasi besar maupun kecil, tetapi data yang dipelajari adalah data dari sampel yang diambil dari populasi tersebut, sehingga ditemukan kejadian relatif, distribusi, dan hubungan antar variabel,sosiologis maupun psikologis.[4].Secara sederhana, Penelitian survey menanyakan kepada beberapa responden tentang kepercayaannya, pendapat-pendapat, karakteristik, dan perilaku yang telah atau sedang terjadi.[5]. penggunaan sampel ini juga sebagai pembeda antara survei dan sensus, karena sensus menggunakan populasi secara keseluruhan.

Munculnya internet telah mengubah cara manusia dalam berkomunikasi,ketersedian jaringan internet yang semakin baik bagi masyarakat akan memudahkan anggota masyarakat untuk berkomunikasi[6],internet adalah jaringan publik luas yang berasal dari komputer dan menghubungkan segala jenis penggunaan di seluruh dunia satu sama lain dan menghubungkan mereka dengan penyimpanan informasi yang sangat besar [7].Semakin berkembangnya teknologi terutama di indonesia membuat semakin banyak pula inovasi inovasi yang di buat. Revolusi industri 4.0 adalah era dimana inovasi inovasi akan teknologi banyak bermunculan. Salah satu karakteristik unik dari industri 4.0 adalah pengaplikasian kecerdasan buatan atau artificial intelligence.[8].Digitalisasi ekonomi, big data, robotic dan sebagainya adalah beberapa contoh dari revolusi industri yang akan terus berkembang seiring waktu. Tidak menutup kemungkinan juga proses survei yang sebelumnya bersifat konvensional dan terkesan tidak praktis akan bisa di gantikan dengan aplikasi Survei online, dimana aplikasi Survei online cenderung lebih praktis,dan mudah dalam pengoperasiannya karena dapat diakses dari mana saja dan kapan saja.

sistem Survei online dinilai sangat efektif untuk menarik minat karena terkesan mengikuti jaman, dengan tampilan yang menarik, desain yang simple dan mekanisme mudah di mengerti. Survei online merupakan salah satu cara pengumpulan data yang dilakuakan dengan menggunakan web atau semacamnya. Banyak keuntungan dalam penggunaan survei online dalam rangka meningkatkan fungsi dari sistem survei yang sudah ada sebelumnya. Sistem survei online ini dapat digunakan pada industri-industri dalam skala besar.[9].

BSA project adalah salah satu perusahaan unit dari CV.Triji Luck yang berfokus pada jasa network engineering di surabaya, sampai dengan saat ini sudah banyak para kustomer yang telah menggunakan jasa BSA Project untuk berbagai keperluan pekerjaan seperti, instalasi jaringan cctv, pembuatan jaringan kabel untuk kebutuhan internet dan lain -lain.untuk meningkatkan kualitas pelayanan pada perusahaan BSA Project juga perlu untuk mensurvei bagaimana hasil kinerja para karyawan BSA Project dalam melayani para customer, sehingga dari hasil survei tersebut perusahaan dapat mengevaluasi serta membenahi apabila terjadi kesalahan.

Program aplikasi yang akan dibuat ini nantiya berupa survei angket, Angket merupakan kumpulan pertanyaanpertanyaan yang tertulis yang digunakan untuk mendapatkan informasi dari responden tentang diri pribadi atau halhal yang diketahui [10].

Dengan adanya uraian latar belakang tersebut maka akan dibuatlah sistem "Aplikasi Survei Online Via Telegram Pada Perusahaan BSA Proect Surabaya" yang dapat menjadi acuan bagi perusahan untuk monitoring dan mengevaluasi kinerja para karyawan,

\section{METODE}

Analisa kebutuhan dan Pengumpulan data untuk penelitian ini dilakukan dengan cara mencari bahan bahan tertulis atau dokumentatif yang masih berhubungan dengan pembahasan masalah yang akan di uraikan dalam penelitian ini, Mencari berbagai informasi yang berkaitan dengan rancang bangun aplikasi dari berbagai sumber seperti di Perpustakaan Universitas Muhammadiyah Sidoarjo ataupun mencari informasi dari berbagai situs dengan menulusuri jaringan media elektronik secara online.

\section{A. Perancangan Sistem}

Tahap awal dari perencanaan adalah proses perancangan sistem yang ada pada perangkat lunak.Untuk mengetahui kondisi sistem tersebut maka dibutuhkan lah tujuan perancangan. Website ini sendiri dirancang menggunakan php agar lebih mudah dan praktis dalam pengoperasiannya. 
Procedia of Engineering and Life Science Vol. 1 No.1 March 2021

Seminar Nasional \& Call Paper Fakultas Sains dan Teknologi (SENASAINS $1^{\text {st }}$ )

Universitas Muhammadiyah Sidoarjo

B. Keterangan Aplikasi

Aplikasi ini merupakan aplikasi survei berbasis website dan dijalan kan dengan bantuan aplikasi telegram pada

smartphone para customer untuk menginputkan data ke dalam database, maksud dari database adalah sebuah program yang bisa untuk menyimpan informasi atau memanipulasi informasi jika diperlukan oleh pemakai .[8].dan untuk aplikasi web akan menampilkan jumlah para pemilih dan hasil rekapitulasi para pemilih yang telah memilih tersebut.

\section{Keamanan Aplikasi}

Untuk mengatasi kemungkinan kecurangan, perancangan sistem ini dibuat dengan melihat potensi potensi kecurangan yang biasanya ada pada sistem survei. Untuk sistem keamanan nya aplikasi ini dirancang untuk mengidentifikasi double survei dimana sistem akan memproses hasil dari input data responden yang sudah di daftarkan nomor nya saja.

\section{Rancangan Pengujian}

Dalam penelitian dibutuhkan beberapa alat dan bahan untuk mendukung berjalanya perancangan dan implementasi program ini.

1. Alat dan Bahan

Untuk mendukung kelancaran pengujian maka dibutuhkan alat antara lain:laptop,smartphone, web browser ,dan aplikasi telegram yang terdapat pada laptop maupun smartphone

2. Objek

Pembuatan program ini ditujukan kepada Perusahaan BSA Project untuk memudahan akses dalam memantau kinerja para karyawan,untuk itu objek pengujian adalah Customer Service sebagai pengguna website tersebut.

3. Tempat

Pengujian dapat dilakukan di tempat yang mempunyai koneksi internet untuk mengakses web.

\section{E. Tahapan Pengujian}

Dalam tahap ini akan dilakukan beberapa pengujian, diantaranya adalah :

a. Pengujian Fungsi dasar Sistem

Tujuan pengujian sistem dasar ini untuk mengetahui kinerja fungsi dasar yang ada di dalam program ini. adapun rencana kasus uji pada pengujian fungsi dasar sistem adalah sebagai berikut:

Tabel 1 Pengujian fungsi dasar sistem

\begin{tabular}{lll}
\hline No. & \multicolumn{1}{c}{ Kasus Uji } & \multicolumn{1}{c}{ Hasil yang diharapkan } \\
\hline 1 & Pengujian fungsi Update & Menampilkan hasil data secara realtime \\
2 & Pengujian fungsi searching & $\begin{array}{l}\text { Sistem dapat menampilkan hasil searching dengan } \\
\text { benar }\end{array}$ \\
& & Sistem dapat mengirim pesan \\
3 & Pengujian fungsi broadcast massage & Sistem dapat menampilkan data pada setiap halaman \\
\hline
\end{tabular}

b. Pengujian user acceptance test

Pengujian dilakukan dengan tujuan untuk seberapa mudah atau sulit dalam penggunaan aplikasi oleh user.Adapun rencana kasus uji pada pengujian performa sistem adalah sebagai berikut: 


\section{HASIL DAN PEMBAHASAN}

\section{A. Halaman Login}

Halaman login merupakan halaman yang digunakan untuk login ke sistem web.

\begin{tabular}{llll}
\hline No. & \multicolumn{1}{c}{ Kasus Uji } & \multicolumn{2}{c}{ Tanggapan User } \\
\hline 1 & Aplikasi mudah dimengerti & Setuju & Tidak \\
2 & Aplikasi mudah digunakan & Setuju & Tidak \\
3 & Aplikasi bermanfaat & Setuju & Tidak \\
4 & Tampilan aplikasi menarik & Setuju & Tidak \\
5 & Aplikasi mudah dipelajari & Setuju & Tidak \\
6 & Tata letak informasi yang terdapat pada layar sangat jelas & Setuju & Tidak \\
7 & Aplikasi nyaman digunakan & Setuju & Tidak \\
8 & Aplikasi mempermudah dalam pekerjaan & Setuju & Tidak \\
9 & Fungsi aplikasi bekerja dengan baik & Setuju & Tidak \\
10 & Aplikasi layak diterapkan sebagai bagian customer monitoring center & Setuju & Tidak \\
\hline
\end{tabular}

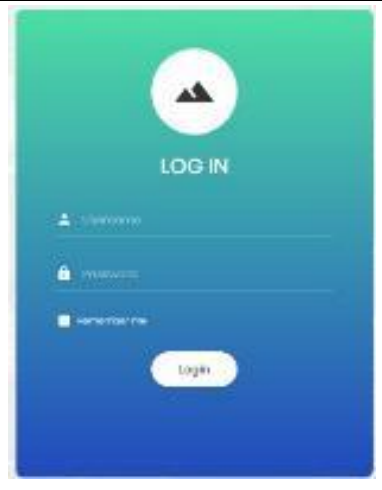

Gambar 1. Halaman Login

Di halaman login ada sebuah form login yang berisi username, password dan tombol login. Jika user menginputkan akun username dan password dengan benar maka jika menekan tombol login akan langsung mengarah ke halaman utama.

\section{B. Halaman Utama}

Halaman utama merupakan halaman yang muncul ketika user login kedalam sistem dengan akun yaitu masuk ke halaman utama. Berikut adalah halaman utama : 
Procedia of Engineering and Life Science Vol. 1 No.1 March 2021

Seminar Nasional \& Call Paper Fakultas Sains dan Teknologi (SENASAINS $1^{\text {st }}$ )

Universitas Muhammadiyah Sidoarjo

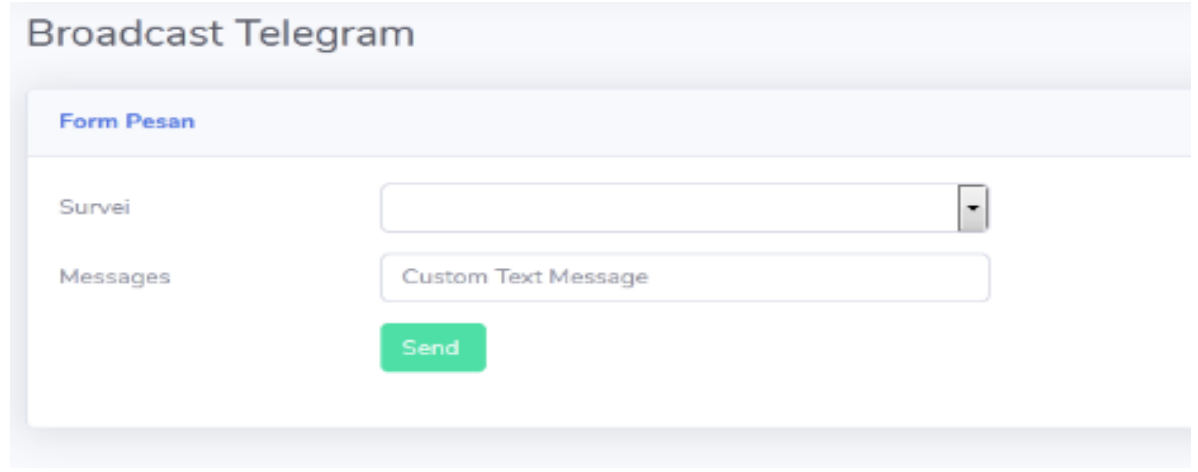

Gambar 2. Halaman Utama

Di halaman utama admin dapat memilih melihat hasil Survei yang sedang atau telah dilakukan

C. Halaman Pendaftaran Survei

Halaman Pendaftaran survei ini adalah halaman untuk menginputkan nama survei,serta waktu dimulai dan waktu berakhirnya survei, Berikut halaman pendaftaran survei :

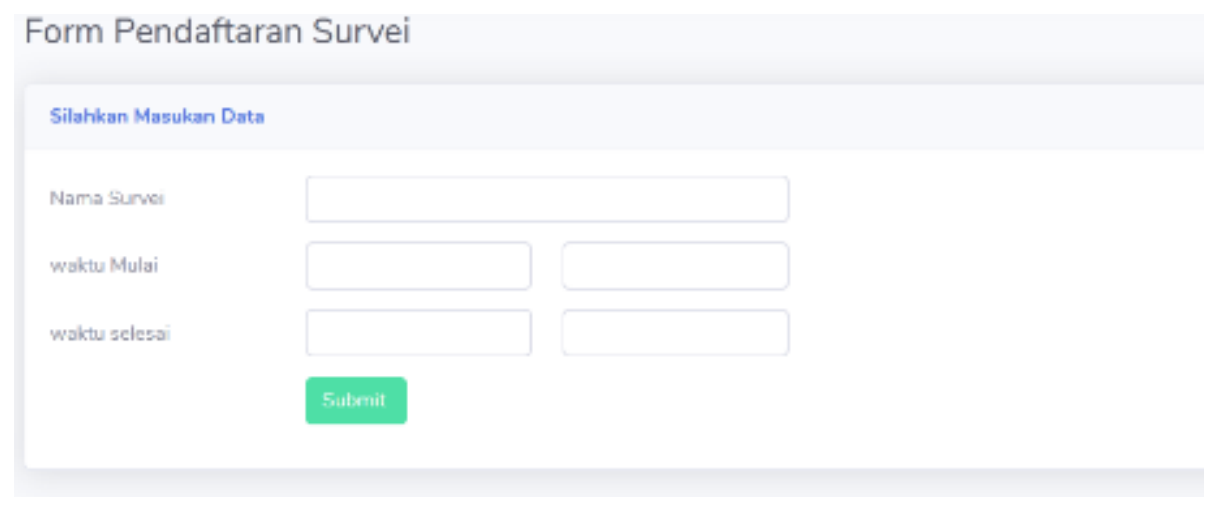

Gambar 3. Halaman Pendaftaran survei

Aplikasi survei ini dibatasi pada waktu tertentu,untuk itu dibuatlah batasan awal dan akhir agar survei dapat dilakukan sesuai jadwal yang telah dikehendaki. Dan berikut script form pendaftaran survei.

D. Halaman Broadcast Survei

Halaman Broadcast survei digunakan pada saat akan mengirim pesan untuk para peserta survei, Berikut halaman broadcast survei : 
Procedia of Engineering and Life Science Vol. 1 No.1 March 2021

Seminar Nasional \& Call Paper Fakultas Sains dan Teknologi (SENASAINS $1^{\text {st }}$ )

Universitas Muhammadiyah Sidoarjo

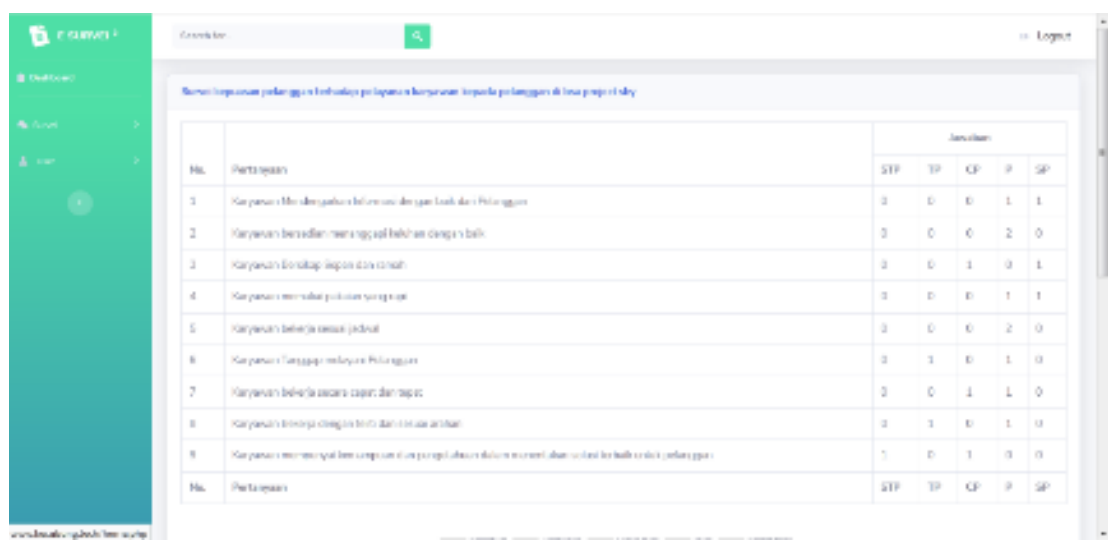

Gambar 4. Halaman Broadcast survei

Jika survei telah dipilih dan pesan pembuka sudah diisi maka selanjutnya tekan tombol send untuk mengirim atau membroadcast kepada seluruh peserta survei yang telah di tentukan.

E. Halaman Managemen Survei

Halaman Managemen survei adalah halaman untuk menghapus ataupun melihat survei yang sedang dilakukan, berikut adalah tampilan halaman survei :

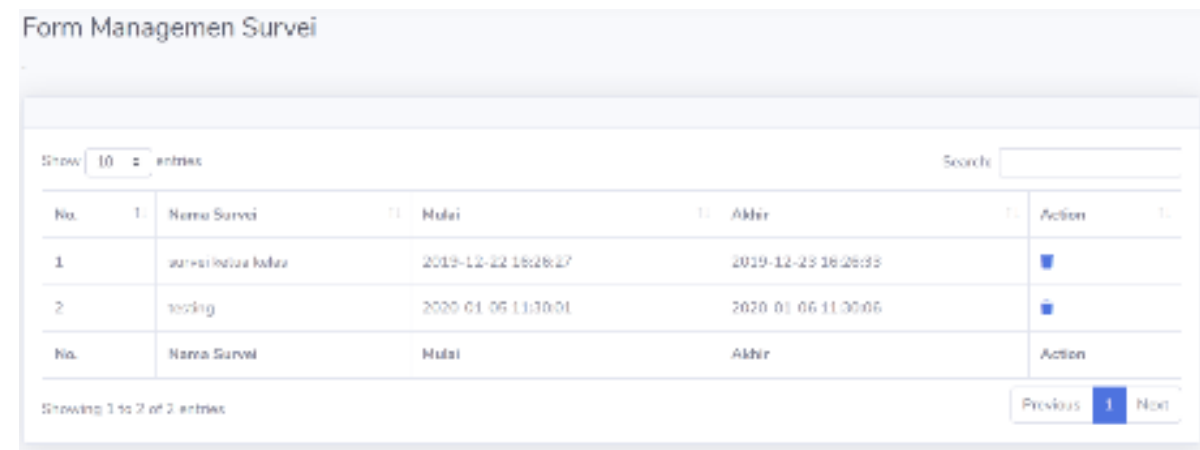

Gambar 5. Halaman Managemen survei

Terdapat satu tombol untuk menghapus survei apabila terjadi kesalahan dalam proses pembuatan survei yang telah dibuat.

\section{F. Halaman Pendaftaran User}

Halaman pendaftaran user adalah halaman untuk menginputkan data user peserta survei. Berikut tampilan halaman pendaftaran user : 
Procedia of Engineering and Life Science Vol. 1 No.1 March 2021

Seminar Nasional \& Call Paper Fakultas Sains dan Teknologi (SENASAINS $1^{\text {st }}$ )

Universitas Muhammadiyah Sidoarjo

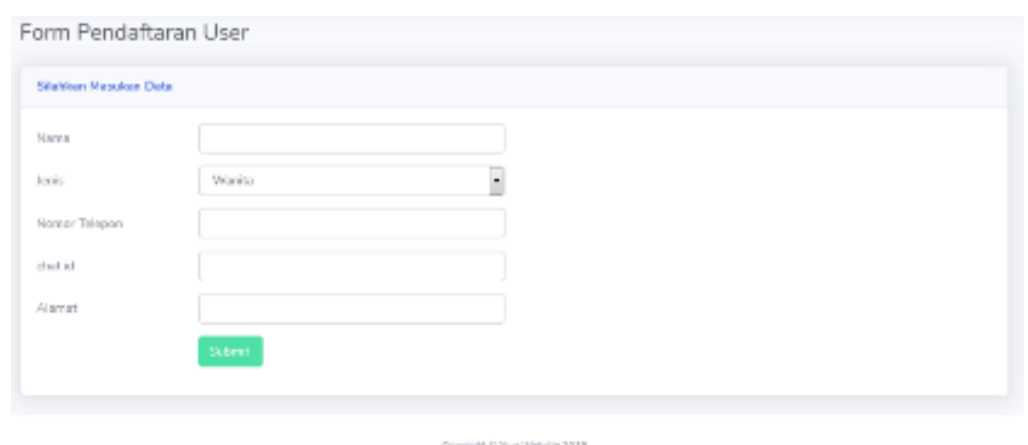

Gambar 6. Halaman Pendaftaran User

G. Halaman Managemen User

Halaman managemen user adalah halaman untuk melihat apakah para peserta sudah melakukan survei atau belum, sekaligus untuk menghapus data survei yang telah dilakukan. Berikut tampilan halaman managemen user :

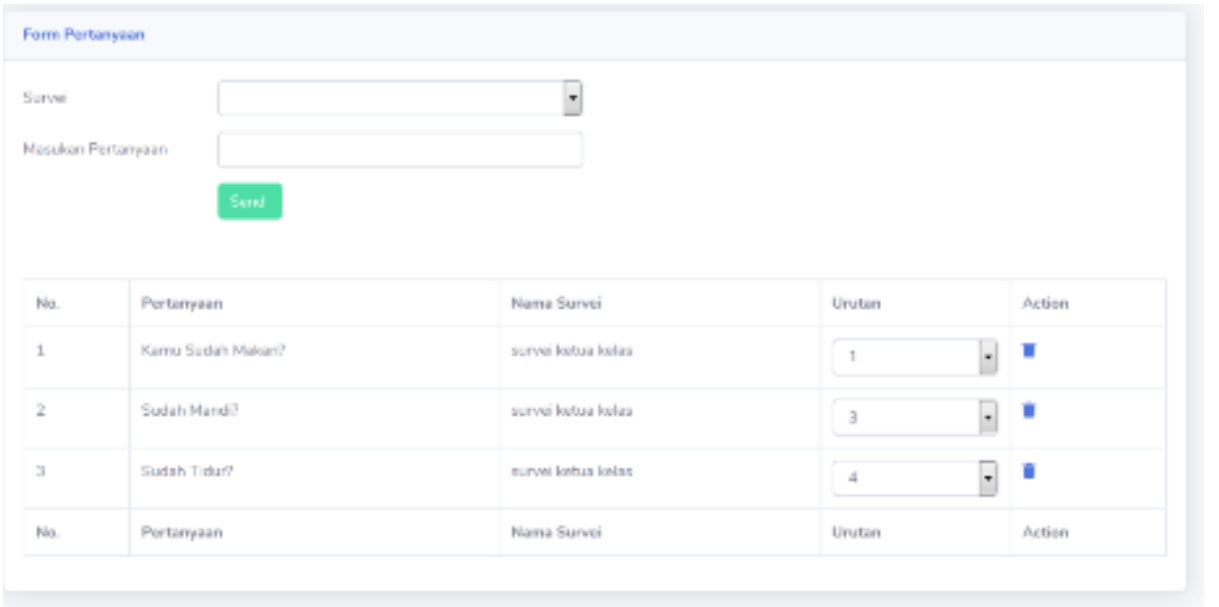

Gambar 7. Halaman Managemen User

Pada Halaman managemen user digunakan untuk melihat informasi ataupun menghapus data dari user tersebut 
Procedia of Engineering and Life Science Vol. 1 No.1 March 2021

Seminar Nasional \& Call Paper Fakultas Sains dan Teknologi (SENASAINS $1^{\text {st }}$ )

Universitas Muhammadiyah Sidoarjo

H. Halaman Input Pertanyaan

Halaman input pertanyaan digunakan untuk menginputkan berbagai pertanyaan yang akan dikirim untuk melengkapi proses survei yang telah dibuat. Berikut adalah tampilan halaman input pertanyaan :

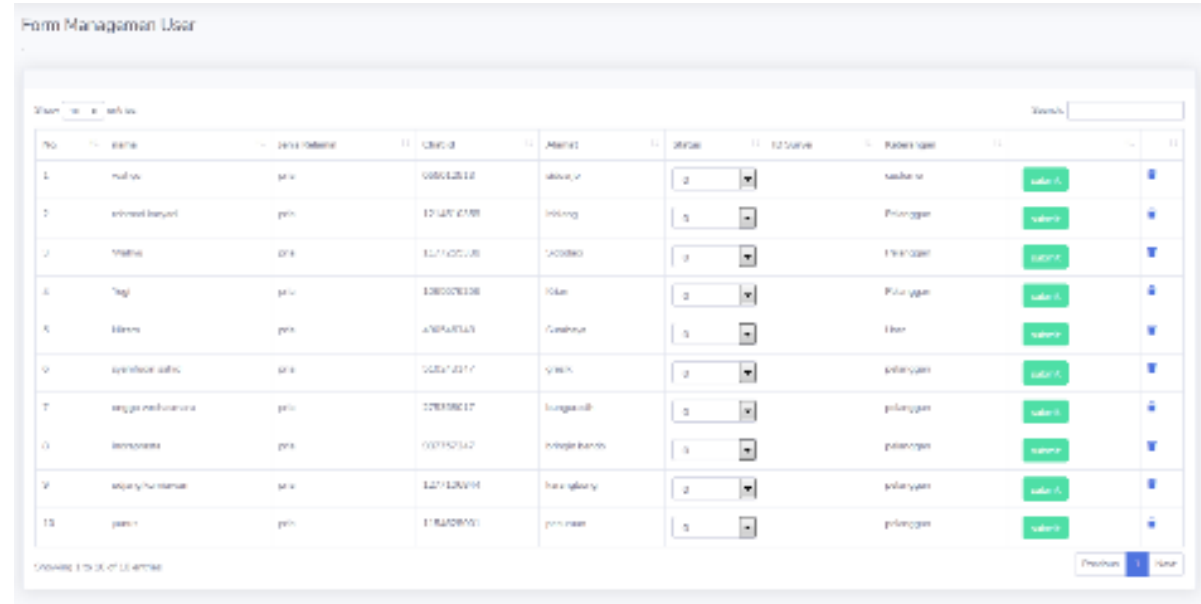

Gambar 8. Halaman Input Pertanyaan

Pada halaman input pertanyaan,admin akan menginputkan berbagai macam pertanyaan yang akan dikirim sebelum proses survei dimulai

\section{Uji Coba Penelitian}

Uji coba penelitian adalah pengujian yang dilakukan secara langsung dengan melakukan testing terhadap penerapan pada aplikasi yang sudah dibuat. Uji coba ini dilakukan sebagai berikut :

1. Hasil uji coba fungsi dasar sistem

Tabel 3 Hasil Uji coba Fungsi dasar sistem

\begin{tabular}{|c|c|c|c|c|}
\hline No. & Kasus Uji & Hasil yang diharapkan & Hasil Pengujian & Keterangan \\
\hline 1 & Pengujian fungsi Update & $\begin{array}{l}\text { Menampilkan hasil data } \\
\text { secara realtime }\end{array}$ & Sesuai Harapan & Valid \\
\hline 2 & Pengujian fungsi searching & $\begin{array}{l}\text { Sistem dapat menampilkan } \\
\text { hasil searching dengan } \\
\text { benar }\end{array}$ & Sesuai Harapan & Valid \\
\hline 3 & $\begin{array}{l}\text { Pengujian fungsi } \quad \text { broadcast } \\
\text { massage }\end{array}$ & $\begin{array}{l}\text { Sistem dapat mengirim } \\
\text { pesan }\end{array}$ & Sesuai Harapan & Valid \\
\hline 4 & Pengujian fungsi paginasi & $\begin{array}{l}\text { Sistem dapat menampilkan } \\
\text { data pada setiap halaman }\end{array}$ & Sesuai Harapan & Valid \\
\hline 5 & $\begin{array}{l}\text { Pengujian fungsi showing entries } \\
\text { per page }\end{array}$ & $\begin{array}{l}\text { Sistem dapat menampilkan } \\
\text { data sesuai jumlah } \\
\text { showing entries per page }\end{array}$ & Sesuai Harapan & Valid \\
\hline 6 & $\begin{array}{l}\text { Pengujian fungsi input database via } \\
\text { telegram }\end{array}$ & $\begin{array}{l}\text { bot telegram dapat } \\
\text { menginputkan ke database } \\
\text { via chating }\end{array}$ & Sesuai Harapan & Valid \\
\hline
\end{tabular}


Procedia of Engineering and Life Science Vol. 1 No.1 March 2021

Seminar Nasional \& Call Paper Fakultas Sains dan Teknologi (SENASAINS $1^{\text {st }}$ )

Universitas Muhammadiyah Sidoarjo

2. Hasil Uji coba user acceptance test

Tabel 4 Hasil Uji coba user acceptance test

\begin{tabular}{|c|c|c|c|c|c|c|}
\hline No. & Kasus Uji & & $\begin{array}{r}\text { Tangge } \\
\text { (pres }\end{array}$ & $\begin{array}{l}\text { an User } \\
\text { tase) }\end{array}$ & & Jumlah \\
\hline 1 & Aplikasi mudah dimengerti & Setuju & $95 \%$ & Tidak & $5 \%$ & 20 \\
\hline 2 & Aplikasi mudah digunakan & Setuju & $90 \%$ & Tidak & $10 \%$ & 20 \\
\hline 3 & Aplikasi bermanfaat & Setuju & $100 \%$ & Tidak & $0 \%$ & 20 \\
\hline 4 & Tampilan aplikasi menarik & Setuju & $75 \%$ & Tidak & $25 \%$ & 20 \\
\hline 5 & Aplikasi mudah dipelajari & Setuju & $85 \%$ & Tidak & $15 \%$ & 20 \\
\hline 6 & $\begin{array}{l}\text { Tata letak informasi yang terdapat pada layar sangat } \\
\text { jelas }\end{array}$ & Setuju & $84,2 \%$ & Tidak & $15,8 \%$ & 20 \\
\hline 7 & Aplikasi nyaman digunakan & Setuju & $80 \%$ & Tidak & $20 \%$ & 20 \\
\hline 8 & Aplikasi mempermudah dalam pekerjaan & Setuju & $95 \%$ & Tidak & $5 \%$ & 20 \\
\hline 9 & Fungsi aplikasi bekerja dengan baik & Setuju & $85 \%$ & Tidak & $15 \%$ & 20 \\
\hline 10 & $\begin{array}{l}\text { Aplikasi layak diterapkan sebagai bagian customer } \\
\text { monitoring center }\end{array}$ & Setuju & $95 \%$ & Tidak & $5 \%$ & 20 \\
\hline
\end{tabular}

Dalam pengujian fungsi dasar sistem yang di lakukan secara langsung dapat di simpulkan bahwa program aplikasi ini dapat berjalan sesuai harapan, kemudian pada hasil uji coba user acceptenance test yang telah di ujikan kepada 20 karyawan dapat di ketahui bahwa presentase untuk tanggapan setuju adalah antara $80 \%$ sampai 100\% , lalu pada pilihan untuk tidak setuju adalah antara $0 \%$ sampai $20 \%$, untuk itu dapat disimpulkan bahwa mayoritas tanggapan user dalam penggunaan program aplikasi ini adalah setuju dan dapat di terima dengan baik oleh karyawan BSA Project Surabaya.

\section{KESIMPULAN}

Berdasarkan hasil pembuatan aplikasi yang telah dilakukan maka dapat di ambil beberapa kesimpulan, yaitu :

1. Penerapan aplikasi Survei online dapat di implementasikan dengan menggunakan server php dan aplikasi telegram chat untuk para responden nya

2. Web survei online dapat dikoneksikan dengan aplikasi telegram, serta hasil nya dapat ditampilkan secara realtime

3. Uji coba fungsi dasar sistem pada aplikasi ini dapat berjalan sesuai harapan

4. Hasil User acceptance test kepada karyawan menyimpulkan bahwa sebagian besar karyawan setuju dalam penggunaannya

\section{UCAPAN TERIMAKASIH}

Ucapan terima kasih ini disampaikan oleh penulis kepada perusahaan bsa Project yang berkenan untuk memberikan data yang diperlukan guna melancarkan penelitian ini.

\section{REFERENSI}

[1] Musa, Mohammad. (1998). Metodologi Penelitian, Jakarta: Fajar Agung.

[2] Musa, Mohammad. (1998). Metodologi Penelitian, Jakarta: Fajar Agung.

[3] Ali, M. (2010). Metodologi dan Aplikasi Riset Pendidikan. Bandung: Pustaka Cendikia Utama

[4] Sugiyono. (2007). Metode Penelitian Kuantitatif Kualitatif dan R\&D. Bandung: Alfabeta 
Procedia of Engineering and Life Science Vol. 1 No.1 March 2021

Seminar Nasional \& Call Paper Fakultas Sains dan Teknologi (SENASAINS $1^{\text {st }}$ )

Universitas Muhammadiyah Sidoarjo

[5] Groves, Robert M., Survey Methodology (2010), Second edition of the (2004) first edition ISBN 0-47148348-6

[6] Hermawan, Agus. 2012. Komunikasi Pemasaran.Jakarta : Erlangga

[7] Kotler, Philip dan Gary Armstrong. 2008. Prinsip-Prinsip Pemasaran. Diterjemahkan oleh : Bob Sabran. Edisi keduabelas. Jilid 2.Jakarta : Erlangga

[8] Tjandrawina, R.R. (2016). Industri 4.0: Revolusi industry abad ini dan pengaruhnya pada bidang kesehatan dan bioteknologi. Jurnal Medicinus, Vol 29, Nomor 1, Edisi April.

[9] M.Burhan. (2009). Metodologi Penelitian Kantitatif. Jakarta: Kencana

[10] Arikunto, Prosedur Penelitian Suatu Pendekatan Praktik. Jakarta: Rineka Cipta, 2006. 